\title{
PERLINDUNGAN HUKUM TERHADAP KORBAN TINDAK PIDANA PENIPUAN MELALUI INTERNET
}

\author{
Dhaniar Eka Budiastanti \\ Fakultas Hukum Universitas Merdeka Malang \\ JI. Terusan Dieng No. 62-64; Malang; 65146; Indonesia; (0341) 580161 \\ debudiastanti@gmail.com
}

\begin{abstract}
The development of technology in addition to bringing positive impact, in its development also bring negative impact. The crime of using the internet as a means of committing crimes has increased substantially in the State of Indonesia as a form of negative impact. The Internet is used as a means to commit a crime, one of which is fraud. The protection granted by the Law of the Republic of Indonesia Number 19 the Year 2016 on Information and Electronic Transactions in the form of settlement of cases and the provision of criminal sanctions provided to the suspect or defendant. Article 28 paragraph (1) of the Law of the Republic of Indonesia Number 19 the Year 2016 on Information and Electronic Transactions may indicate as the article regulating fraud, but if examined more deeply, the elements contained in Article 28 paragraph (1) Law -The Republic of Indonesia No. 19 of 2016 on Information and Electronic Transactions is still considered less to meet the elements contained in the act that provides fictitious information in terms of sales of goods in cyberspace. Another case with Article 378 of the Criminal Code, which detailed parse elements of acts that provide fictitious information.
\end{abstract}

Keywords:Fraud, Internet, Legal Protection.

\begin{abstract}
Abstrak
Perkembangan teknologi disamping membawa dampak positif, dalam perkembangannya juga membawa dampak negatif. Kejahatan menggunakan internet sebagai sarana untuk melakukan kejahatan mengalami peningkatan cukup tinggi di Negara Indonesia merupakan bentuk dampk negatiftersebut.Internet digunakan sebagai sarana untuk melakukan tindak pidana, yang salah satunya adalah penipuan. Perlindungan yang diberikan oleh Undang-Undang Republik Indonesia Nomor 19 Tahun 2016 tentang Informasi dan Transaksi Elektronik berupa penyelesaian perkara dan pemberian sanksi pidana yang diberikan kepada tersangka atau terdakwa.Pasal 28 ayat (1) Undang-UndangRepublik Indonesia Nomor 19 Tahun 2016 tentang Informasi dan Transaksi Elektronikdapat indikasikan sebagai pasal yang mengatur mengenai penipuan, akan tetapi jika dikaji lebih dalam lagi, unsur-unsur yang terdapat pada pasal 28 ayat (1) Undang-Undang Republik Indonesia Nomor 19 Tahun 2016 tentang Informasi dan Transaksi Elektronik ini masih dirasa kurang untuk memenuhi unsur-unsur yang terdapat di dalam perbuatan yang memberikan informasi fiktif dalam hal penjualan barang di dunia maya. Lain halnya dengan Pasal 378 KUHP, yang rinci mengurai unsur-unsur perbuatan yang memberikan informasi fiktif.
\end{abstract}

Kata Kunci:Penipuan, Internet,Perlindungan Hukum. 


\section{Perlindungan Hukum terhadap Korban Tindak Pidana Penipuan Melalui Internet}

Dhaniar Eka Budiastanti

Kemajuan tekhnologi yang merupakan hasil budaya manusia disamping membawa dampak positif, dalam hal ini berarti dapat dipergunakan bagi manusia dengan baik, ternyata dalam perkembangannya juga dapat membawa dampak negatif bagi manusia dan lingkungannya. Dampak negatif yang dimaksudkan dalam konteks ini adalah terjadinya kejahatan di Internet.

Salah satu jenis kehatahan yang ditimbulkan oleh perkembangan dan kemajuan tekhnologi informasi adalah kejahatan yang berkaitan dengan pemanfaatan aplikasi dari internet, yang sering disebut dengan cyber crime. Cyber crime adalah kejahatan yang dilakukan di dunia maya atau internet (Fajri, 2000). Saat ini banyak sekali terjadi penyalahgunaan internet dan internet dapat berubah menjadi sarana untuk melakukan kejahatan atau tindak pidana. Kejahatan yang berkaitan dengan tekhnologi informasi dapat dibagi menjadi dua bagian besar.

Pertama, kejahatan yang bertujuan merusak atau menyerang sistem atau jaringan komputer, sedangkan yang kedua adalah kejahatan yang menggunakan komputer atau internet sebagai alat bantu dalam melancarkan kejahatan (Wahid \&Labib, 2005). Namun pembahasan dalam penelitian ini penulis lebih memfokuskan pada jenis kejahatan teknologi informasi yang kedua, yaitu internet sebagai alat bantu dalam melancarkan kejahatan.

Namun demikian di dalam pembahasan penelitian ini lebih memfokuskan situs di Internet (website) sebegai media perantara untuk melakukan transaksi melalui internet, dimana isi dari situs di internet (website) tersebut seolah-olah terdapat kegiatan penjualan barang. Kegiatan transaksi melalui internet yang menggunakan website sebagai medianya, dalam hal ini misalnya jual beli, tentu memiliki resiko yang harus di tanggung oleh pihak pembeli (peminat barang).

Salah satu resikonya adalah ketika informasi yang terdapat pada website yang menawarkan suatu barang adalah palsu dan peminat dari barang yang terdapat pada website tersebut telah mentransfer sejumlah uang ke rekening contact person yang terdapat pada website, akan tetapi barang yang dikehendaki oleh peminat tidak sampai ke tangan peminat.

Saat ini Indonesia telah memiliki Undangundang yang khusus untuk mengatur mengenai cyber crime/ kejahatan mayatara, yaitu UndangUndang Republik Indonesia Nomor 19 Tahun 2016 tentang Perubahan Atas Undang-Undang Republik Indonesia Nomor 11 Tahun 2008 tentang Informasi dan Transaksi Elektronik, yang selanjutnya disebut dengan UU ITE. UU ITE dirasa perlu untuk diberlakukan dan terus diperbaharui.

Pasal 28 Ayat (1) UU ITE telah mengatur mengenai perbuatan yang dilarang dalam transaksi elektronik, yang berisi mengenai setiap orang dilarang untuk menyebarkan berita bohong dan menyesatkan secara sengaja dan tanpa hak yang dapat merugikan konsumen dalam transaksi elektronik, sedangkan mengenai sanksi pidana yang diberikan atas perbuatan pada Pasal 28 Ayat (1) UU ITE tersebut diatur dalam ketentuan pidana yang terdapat pada Pasal 45A Ayat (1) UU ITE.

Pasal 28 Ayat (1) UU ITE tersebut dapat indikasikan sebagai pasal yang mengatur mengenai perbuatan yang seolah-olah memberikan informasi yang benar dalam hal penjualan barang di dunia maya, akan tetapi jika dikaji lebih dalam lagi, unsur-unsur yang terdapat pada Pasal 28 Ayat (1) UU ITE ini masih dirasa kurang untuk memenuhi unsur-unsur yang terdapat di dalam perbuatan yang memberikan informasi fiktif dalam hal penjualan barang di dunia maya. Lain halnya dengan KUHP (Pasal 378 KUHP), yang begitu rinci mengurai unsur-unsur perbuatan yang memberikan informasi fiktif. Hal ini tentu saja menarik perhatian untuk mengkaji lebih dalam mengenai perlindungan hukum UU ITE terhadap korban penipuan melalui internet. 
Berdasarkan hal tersebut, maka dapat ditarik rumusan masalah sebagai berikut: Bagaimana aspek yuridis tindak pidana penipuan melalui internet ditinjau dari KUHP dan UU ITE. Bagaimanakah perlindungan hukum yang diberikan UU ITE terhadaphak-hak korban penipuan melalui internet. Bagaimana kebijakan perlindungan hukum Bagi Korban Tindak Pidana Penipuan melalui internet.

\section{Metode Penelitian}

Jenis penelitian yang digunakan dalam ini penelitian adalah Yuridis Normatif. Sehubungan dengan jenis penelitian yang digunakan adalah yuridis normatif, maka pendekatan penelitian yang digunakan dalam penulisan ini adalah Statute Approach dengan metode Comparative Approach. Penulisan ini menggunakan jenis bahan hukum primer, sekunder dan tersier. Penulis menggunakan bahan hukum primer yang di susun berdasarkan skala prioritas yang menjadi fokus utama, sedangkan perturan perundang-undangan lainnya sebagai pembanding. Bahan hukum primer tersebut adalah sebagai berikut:Undang-undang Dasar Negara Republik Indonesia Tahun 1945;Undang-undang Nomor 19 Tahun 2016 tentang Informasi dan Transaksi Elektronik;KUHP (Kitab Undangundang Hukum Pidana); Undang-undang Nomor 31 Tahun 2014 tentang Perlindungan Saksi dan Korban; dan KUHAP (Kitab Undang-undang Hukum Acara Pidana).

Teknik penelusuran dalam penelitian ini menggunakan cara studi kepustakaan. Metode analisis data dalam penelitian ini adalah metode analisis isi (statue analisys) yaitu dengan mencermati substansi perundang-undangan dan berbagai doktrin, teori-teori Cyber Crime dan melakukan interpretasi secara gramatikal, ekstensif dan terhadap doktrin dan teori tersebut dalam mengkaji perlindungan hukum Undang-undang Nomor 19 Tahun 2016 tentang Informasi dan Transaksi Elektronik terhadap korban penipuan melalui internet.

\section{Aspek Yuridis Tindak Pidana Penipuan Melalui Internet dalam KUHP dan UU ITE}

\section{Tindak Pidana Penipuan Melalui Internet Berdasarkan KUHP}

Konsepsi mengenai penipuan adalah, pertama, bahwa penipuan adalah tindak pidana materiil (Rubai, 2001). Penipuan memerlukan hubungan causal subjektif ( $p$ sychische causaliteit) antara perbuatan menggerakkan. Menggerakkan adalah perbuatan mempengaruhi kehendak orang lain, agar kehendak orang tersebut terbentuk sesuai yang diinginkan pembuat yang untuk menyerahkan barang kepadanya. Harus terbentuk kehendak terlebih dahulu bagi korban penipuan tersebut, barulah dengan sukarela korban menyerahkan barang miliknya.

Orang tersebut menyerahkan barang secara sukarela, tapi tidak sadar kalau sudah terpedaya. Sebagai tindak pidana materiil, selesainya tindak pidana ini tidak cukup pada telah terbentuknya kehendak orang yang ditipu, melainkan dari terbentuknya kehendak untuk menyerahkan barang, membuat utang atau menghapuskan piutang tersebut, orang itu telah benar-benar terbukti menyerahkan barangnya, utang telah dibuat dan piutang telah dihapuskan. Kedua, cara menggerakkan kehendak orang lain tersebut, dengan menggunakan nama palsu, tipu muslihat, rangkaian kebohongan dan kedudukan atau martabat palsu. Cara yang isinya palsu terdapat sifat melawan hukum objektif dan sifat melawan hukum materiil penipuan (Chazawi, 2010).

Ketentuan yang menjerat mengenai penipuan dalam KUHP, adalah terdapat pada Pasal 378 KUHP. Apabila dikaitkan dengan tindak pidana penipuan melalui internet, maka telah memenuhi unsur-unsur yang terdapat pada Pasal 378 KUHP. a. Unsur Obyektif Penipuan dalam KUHP

1) Perbuatan Menggerakkan (Bewegen) Cara menggerakkan pada penipuan harus dengan cara-cara yang palsu dan bersifat membohongi atau tidak benar, karena jika 
menggerakkan di lakukan dengan cara yang sesungguhnya, cara yang benar dan tidak palsu, maka tidak mungkin kehendak orang lain (korban) akan menjadi terpengaruh, yang pada akhirnyaia menyerahkan benda, memberi hutang maupun meghapuskan piutang. Tujuan yang ingin dicapai pelaku dalam penipuan hanya mungkin bisa dicapai dengan melalui perbuatan menggerakkan yang menggunakan cara-cara yang tidak benar (Chazawi, 2003).

Apabila dihubungkan dengan kejahatan penipuan melalui internet, maka hal tersebut telah memenuhi unsur menggerakkan pada Pasal 378 KUHP.

2) Objek yang Digerakkan Adalah Orang Kepada siapa diberinya utang atau dihapuskannya piutang tidak perlu kepada atau bagi kepentingan orang yang menggerakkan (petindak). Penyerahan benda dapat dilakukan kepada orang lain, selain orang yang menggerakkan, asalkan perantara ini adalah orang yang dikehendaki petindak (Chazawi, 2003).

Terkait dengan tindak pidana penipuan melalui internet dengan menggunakan modus jual beli melalui suatu situs tertentu, maka yang di gerakkan adalah orang untuk menguntungkan pembuat kehendak (petindak) atau pihak ketiga atas persetujuan dari pembuat kehendak.

3) Menyerahkan Benda

Penipuan melalui internet terjadi bukan karena telah terjadinya perbuatan menggerakkan, melainkan pada telah terjadinya perbuatan menyerahkan benda oleh orang lain. Menyerakhan benda itu baru dianggap terjadi atau selesai apabila dari perbuatan tersebut, telah sepenuhnya berpindahya kekuasaan atas benda itu ke dalam kekuasaan orang menerima.
4) Memberikan Hutang dan Menghapuskan Piutang

Arti kata hutang dalam penipuan ini tidaklah sama dengan hutang piutang, melainkan diartikan sebagai suatu perjanjian atau perikatan. Memberi hutang tidak dapat diartikan sebagai member pinjaman kepada seseorang, melainkan terdapat pengertian yang lebih luas, yaitu membuat suatu perikatan hukum yang membawa akibat timbulnya kewajiban bagi orang lain untuk menyerahkan atau membayarkan sejumlah uang tertentu (Chazawi, 2003).

Terkait dengan penipuan melalui internet, maka dalam suatu penipuan jual beli, maka akan timbul suatu kewajiban bagi seseorang (korban, yang dalam hal ini adalah pembeli) untuk membayarkan sejumlah uang sesuai dengan produk yang ditawarkan oleh petindak (penjual).

5) Upaya Penipuan dengan Menggunakan Nama Palsu

Penipu biasanya menggunakan nama palsu baik nama itu suatu nama yang bukan namanya sendiri, maupun suatu nama yang tidak diketahui siapa pemilik dari nama tersebut. Hal ini dilakukan penindak, agar identitasnya yang asli tidak terbuka, guna menghindari apabila menimbulkan suatu akibat hukum di kemudian hari.

6) Upaya Penipuan dengan Menggunakan Martabat atau Kedudukan Palsu (valsche hoedanigheid)

Kedudukan palsu itu adalah suatu kedudukan yang disebut atau digunakan seseorang, kedudukan mana menciptakan atau mempunyai hak-hak tertentu, padahal sesungguhnya tidak mempunyai hak tersebut (Chazawi, 2003). 
7) Menggunakan Tipu Muslihat (Listige Kunstgrepen) dan Rangkaian Kebohongan (Zamenweefsel van Verdichtsels)

Menggunakan tipu muslihat dan rangkaian kebohongan, sama-sama memiliki sifat menipu atau isinya tidak benar atau palsu, namun dapat menimbulkan kepercayaan atau kesan bagi orang lain bahwa semuanya seolah-olah benar. Namun, terdapat perbedaan antara tipu muslihat dan rangkaian kebohongan, yaitu pada tipu muslihat berupa perbuatan, sedangkan pada rangkaian kebohongan berupa ucapan atau perkataan (Chazawi, 2003).

Petindak menggunakan sarana internet untuk melakukan penipuan, sehingga hanya menggunakan perkataan atau ucapan yang diragkai dalam bentuk tulisan di suatu situs dan memiliki unsur-unsur tertentu, yaitu pertama berupa perkataan yang isinya tidak benar, kedua lebih dari satu bohong, dan ketigabohong yang satu akan menguatkan bohong yang lainnya.

b. Unsur Subjektif Penipuan dalam KUHP

1) Maksud untuk Menguntungkan Diri Sendiri atau Orang Lain

Pelaku penipuan melalui internet, biasanya lebih dominan ditujukan untuk menguntungkan dirinya sendiri. Menguntungkan dalam hal ini dapat diartikan sebagai menambah kekayaan dari yang sudah ada. Kesengajaan sebagai maksud ini harus sudah ada dalam diri petindak, sebelum atau setidak-tidaknya pada saat memulai perbuatan menggerakkan.

2) Melawan Hukum

Artinya unsur melawan hukum tersebut merupakan unsur subjektif, dimana sebelum melakukan atau setidak-tidaknya ketika memulai perbuatan menggerakkan, petindak telah memiliki kesadaran dalam dirinya bahwa perbuatan menguntungkan diri sendiri tersebut merupakan perbuatan melawan hukum.
KUHP tidak dapat menjerat pelaku penipuan melalui internet, karena merupakan tindak pidana cybercrime yang pelakunya berada di dunia maya, yang bisa ditindak dengan KUHP adalah penipuan biasa (kejahatan konvensional), dimana pelakunya juga berada pada dunia nyata. Oleh karena itu, penjeratan penipuan melalui internet harus menggunakan UU ITE karena segala macam ketentuan tentang informasi dan transaksi elektronik serta cybercrime ada pada peraturan tersebut.

Mengenai pengaturan tindak pidana penipuan melalui internet, tidak terjadi benturan peraturan antara KUHP dan Undang-Undang Republik Indonesia Nomor 19 Tahun 2016 tentang Informasi dan Transaksi Elektronik, bahkan kedua peraturan tersebut saling melengkapi dan mengisi. Kedua UU tersebut dapat digunakan secara bersamaan (Jo) dengan ketentuan Lex Specialis derogat legi Generali, yang artinya Peraturan Undangundang yang bersifat khusus mengesampingkan peraturan Undang-Undang yang bersifat umum. Dengan demikian UU ITE didahulukan karena memiliki kekhususan untuk menjerat tindak pidana penipuan melalui internet dan KUHP adalah sebagai Undang Undang yang menjelaskan tentang unsur-unsur penipuan. Junto adalah kata sifat yang berasal dari bahasa Spanyol yang mempunyai arti "bersama" (Prodjodikoro, 2003).

\section{Tindak Pidana Penipuan Melalui Internet Berdasarkan Undang-Undang Republik In- donesia Nomor 19 Tahun 2016 tentang Informasi dan Transaksi Elektronik}

Penyusunan UU ITE, di dasarkan pada beberapa alternatif model pengaturan, diantarannya, pertama model pengaturan yang berpijak pada pemilahan materi hukum secara ketat sehingga regulasi yang dibuat bersifat sangat sempit dan spesifik pada sektor tertentu saja, kedua model pengaturan yang bersifat komprehensif dalam arti materi muatan yang diatur mencakup hal yang lebih luas disesuaikan dengan kebutuhan yang saat ini terjadi sehingga dalam regulasi tersebut akan ter- 
cakup aspek hukum perdata materil, hukum acara perdata dan pidana (walaupun dapat berupa kaidah penunjuk berlakunya hukum tertentu), hukum pembuktian, dan hukum pidana. Model kedua ini yang dijadikan acuan untuk membuat UU ITE (RUU ITE).

Terdapat beberapa asas yang perlu untuk diperhatikan dalam penyusunan UU ITE. Asas diperlukan dalam pembentukan suatu perundangundangan, karena asas merupakan pikiran-pikiran yang memberi arah atau pimpinan, yang menjadi dasar kepada tata hukum yang ada sebagaimana dipositifkan dalam perundang-undangan, jurisprudensi dan untuk sebagian berasal dari kesadaran hukum atau keyakinan kesusilaan.

Asas dalam pembentukan UU ITE tersebut ditujukan untuk mencerdaskan kehidupan bangsa yang merupakan bagian dari Pembukaan UndangUndang Dasar Republik Indonesia Tahun 1945. Pasal 28 F Undang-Undang Dasar Republik Indonesia Tahun 1945 mengamanatkan bahwa setiap orang berhak untuk berkomunikasi dan memperoleh informasi untuk mengembangkan pribadi dan lingkungan sosialnya, serta berhak untuk mencari, memperoleh, memiliki, menyimpan, mengolah, dan menyampaikan informasi dengan menggunakan saluran yang tersedia.

Berdasarkan pasal 28 F Undang-Undang Dasar Republik Indonesia Tahun 1945 tersebut, maka dapat dikatakan bahwa dengan di bentuknya UU ITE, berarti telah membatasi penggunaan tekhnologi informasi. Akan tetapi yang perlu ditegaskan adalah UU ITE dibentuk guna mengatur segala pemanfaatan elektronik secara bebas akan tetapi bertanggungjawab.

Terkait dengan penggunaan internet, yang merupakan pemanfaatan dari teknologi informasi dan transaksi elektronik, oleh karena itu harus dilakukan sesuai dengan Pasal 3 UU ITE.

Pelaksanaannya para pelaku atau penyelenggara sistem elektronik memiliki kewajiban seperti yang tertulis pada Pasal 15 UU ITE, yaitu:
1) Setiap Penyelenggara Sistem Elektronik harus menyelenggarakan Sistem Elektronik secara andal dan aman serta bertanggung jawab terhadap beroperasinya Sistem Elektronik sebagaimana mestinya.

2) Penyelenggaraan Sistem Elektronik bertanggung jawab terhadap Penyelenggaraan Sistem Elektroniknya.

3) Ketentuan sebagaimana dimaksud pada ayat (2) tidak berlaku dalam hal dibuktikan terjadinya keadaan memaksa, kesalahan, dan/atau kelalaian pihak pengguna Sistem Elektronik.

Bagi para pengguna yang memanfaatkan situs forum atau web untuk melakukan penipuan dengan cara memberikan informasi palsu dan melakukan serangkaian kebohongan untuk membeli suatu produk yang di tawarkan, dalam hal ini berarti telah melakukan tindak pidana penipuan dan melanggar ketentuan Pasal 28 Ayat (1) UU ITE, yang berisi sebagai berikut: "Setiap Orang dengan sengaja dan tanpa hak menyebarkan berita bohong dan menyesatkan yang mengakibatkan kerugian konsumen dalam Transaksi Elektronik."

a) Unsur Objektif UU ITE Pasal 28 UU ITE

1) Perbuatannya: Menyebarkan: Perbuatan menyebarkan yang dimaksud dalam Pasal 28 (1) UU ITE.

2) Mengakibatkan Kerugian Konsumen dalam Transaksi Elektronik: Kerugian konsumen dalam transaksi elektronik merupakan suatu akibat dari adanya transaksi elektronik yang dilakukan secara melawan hukum atau melanggar peraturan perundang-undangan.

b) Unsur Subjektif UU ITE Pasal 28 UU ITE

1) Dengan Sengaja: Unsur dengan sengaja pada Pasal 28 Ayat (1) ini dimaksud pada perbuatan yang menyebarkan berita bohong dengan menggunakan internet sebagai medianya.

2) Tanpa Hak (Melawan Hukum): Terkait dengan penipuan melalui internet, petindak 
yang menyebarkan informasi (iklan) yang palsu berarti telah melakukan perbuatan melawan hukum. Ketentuan pidana yang mengatur mengenai perbuatan penipuan melalui internet, sebagaimana yang terdapat pada Pasal 28 Ayat (1) UU ITE, telah diatur dalam Pasal 45 aAyat (1) UU ITE.

c) Unsur Obyektif Pasal 37 UU ITE

1) Perbuatan:Melakukan perbuatan yang dimaksud dalam Pasal 27 UU ITE sampai dengan Pasal 36 UU ITE di luar wilayah Indonesia;

2) Objeknya:Sistem Elektronik; dan

3) Di wilayah yurisdiksi Indonesia.

d) Unsur Subjektif Pasal 37 UU ITE

1) Dengan sengaja; dan

2) Melawan hukum (perbuatan yang dilarang).

Unsur obyektif pada perbuatan adalah melakukan kegiatan yang tercantum pada Pasal 27 UU ITE sampai dengan Pasal 36 UU ITE mengenai perbuatan yang dilarang dalam melakukan transaksi elektronik di luar wilayah Indonesia yang objeknya adalah sistem elektronik di wilayah yurisdiksi Indonesia.

Terhadap unsur subjektif perbuatan adalah dengan sengaja dan melawan hukum (melakukan perbuatan yang dilarang). Berdasarkan isi Pasal 37 UU ITE, apabila orang yang melakukan penipuan berada di luar wilayah Indonesia, dan membawa akibat hukum di wilayah Indonesia, maka pelaku tetap dapat dikenai sanksi pidana yang dapat menjerat pelaku penipuan melalui internet, yaitu Pasal 45 aAyat (1) UU ITE.

\section{Perlindungan Hukum Terkait Korban Tindak Pidana Penipuan Korban Tindak Pidana Melalui Internet}

Korban kejahatan penting untuk dilindungi, karena pertama, masyarakat dianggap sebagai suatu wujud sistem kepercayaan yang melembaga (system of institutionalized trust). Kepercayaan ini terpadu melalui norma-norma yang diekspresikan di dalam struktur kelembagaan, seperti kepolisian, kejaksaan, pengadilan, dan lain sebagainya. Terjadinya kejahatan atas diri korban dapat bermakna penghancuran sistem kepercayaan tersebut, sehingga pengaturan hukum pidana dan hukum lain yang menyangkut korban akan berfungsi sebagai sarana pengembalian sistem kepercayaan tersebut.

Kedua, adanya argument kontrak sosial dan solidaritas karena negara boleh dikatakan memonopoli seluruh rekasi sosial terhadap kejahatan yang melarang tindakan-tindakan yang bersifat pribadi. Oleh karena itu, jika terdapat korban kejahatan, maka negara harus memperhatikan seluruh korban dengan cara peningkatan pelayanan maupun pengaturan hak. Ketiga, perlindungan korban yang biasanya dikaitkan dengan salah satu tujuan pemidanaan, yaitu penyelesaian konflik. Penyelesaian konflik yang ditimbulkan oleh adanya tindak pidana akan memulihkan keseimbangan dan mendatangkan rasa damai dalam masyarakat (Mansyur, et.al., 2005).

Mengacu pada penerapan perlindungan hakhak korban kejahatan, diantarany korban penipuan melalui internet sebagai akibat terlanggarnya hak asasi yang bersangkutan, maka dasar perlindungan korban kejahatan dapat dilihat dari beberapa teori, diantaranya adalah sebagai berikut (Mansyur, et.al., 2005):

a) Teori Utilitas, Teori ini menitikberatkan pada kemanfaatan yang terbesar bagi jumlah yang terbesar. Konsep pemberian perlindungan pada korban kejahatan, diantaranya korban penipuan melalui internet dapat diterapkan sepanjang memberikan kemanfaatan yang lebih besar dibandingkan dengan tidak diterapkannya konsep tersebut, tidak saja bagi korban kejahatan, tetapi juga bagi penegakan hukum pidana secara keseluruhan.

b) Teori Tanggungjawab, Subjek hukum hakikatnya bertanggungjawab terhadap segala perbuatan hukum 
yang dilakukannya sehingga apabila seseorang melakukan suatu tindak pidana dan mengakibatkan seseorang menderita, kerugian (dalam arti luas), orang tersebut harus bertanggungjawab atas kerugian yang ditimbulkan, kecuali ada alasan yang membebaskannya. Terkait dengan pelaku tindak pidana penipuan melalui internet, berdasarkan teori tanggungjawab, maka pelaku harus mempertanggungjawabkan perbuatan hukum yang dilakukanya, kecuali terdapat alasan untuk membebaskan pelaku tersebut.

c) Teori Ganti Kerugian, sebagai perwujudan tanggungjawab, karena kesalahannya terhadap orang lain, pelaku tindak pidana di bebani kewajiban untuk memberikan kerugian pada orang atau ahli warisnya. Terkait dengan penipuan melalui internet, berdasarkan teori ganti rugi, maka pelaku harus mengganti kerugian apabila korban melakukan tuntutan ganti rugi. Ganti kerugian ini dapat dilakukan dengan menggabbungkan perkara perdata dan perkara pidana sesuai dengan jetentuan pasal 98 sampai dengan pasal 101 KUHAP.

Korban atas terjadinya suatu tindak pidana dalam transaksi elektronik, salah satunya korban penipuan melalui internet merupakan pihak yang paling menderita dan dirugikan, oleh karena itu diperlukan adanya suatu perlindungan dari negara. Hak-hak korban harus dipandang sebagai bentuk perlakuan yang sama bagi setiap orang di muka hukum (equality before the law).

Namun, sayangnya UU ITE tidak mengatur secara jelas mengenai perlindungan yang di berikan kepada korban atas terjadinya tindak pidana dalam melakukan transaksi elektronik. UU ITE hanya mengatur secara tersurat mengenai hak korban apabila terjadi tindak pidana dalam transaksi elektronik, diantaranya penipuan melalui internet, yaitu hak atas penyelesaikan perkara dan pemidanakan orang yang telah melakukan tindak pidana.
Hak korban atas pemidanan orang yang telah melakukan tindak pidana ini terkait dengan tujuan pemidanaan, yaitu untuk mencegah dilakukannya kejahatan pada masa yang akan datang (Prijatno, 2006). Hak korban atas pemidanaan pelaku tindak pidana transaksi elektronik dalam UU ITE ditandai dengan adanya ketentuan pidana yang terdapat pada Pasal 45 sampai dengan Pasal 52 UU ITE. Terkait dengan hak korban atas pemidanaan pelaku penipuan melalui internet, terdapat pada Pasal 45 Ayat (1) UU ITE, yang menjatuhkan pidana pada pelaku berupa pidana penjara dan pidana denda.

Hak korban penipuan melalui internet yang berkaitan dengan penyelesaian perkara, dapat diketahui dengan adanya substansi hukum formil dalam UU ITE, mengenai penyidikan yang terdapat padal Pasal 42 sampai dengan Pasal 44 UU ITE. Hak korban atas penyelesain perkara, selain diatur oleh UU ITE, dalam penerapannya berkaitan erat dengan KUHAP dalam proses penyelesaian perkara pidana.

Terkait dengan korban tindak pidana, seperti halnya korban tindak pidana penipuan melalui internet, KUHAP, telah mengatur beberapa hak mengenai korban kejahatan. Namun, hak yang diberikan kepada korban dalam KUHP, sangatlah minim, dibandingkan hak-hak yang diberikan kepada tersangka atau terdakwa.

Hal di atas tentu saja bertentangan dengan pertimbangan pada huruf (a) KUHAP, yang menyatakan bahwa Negara Republik Indonesia adalah Negara Hukum berdasarkan UUD 1945, yang menjunjung tinggi hak asasi manusia serta menjamin segala warganegara bersamaan kedudukannya di hadapan hukum, pemerintahan dan wajib menjunjung hukum dan pemerintahan itu dengan tidak ada kecualinya.

Hak-hak korban dalam KUHAP yang relevan dengan hak korban tindak pidana penipuan melalui internet, adalah sebagai berikut: 
a) Hak Untuk Melakukan Laporan (Pasal 108 Ayat (1) KUHAP)

b) Hak Untuk Melakukan Kontrol Terhadap Penyidik dan Penuntut Umum (pasal 77 jo 80 KUHAP)

c) Hak Untuk Menuntut Ganti Rugi Akibat Suatu Tindak Pidana Melalui Cara Penggabungan Perkara Perdata dengan Perkara Pidana (Pasal 98 sampai dengan pasal 101 KUHAP)

Terkait dengan perlindungan terhadap korban, terdapat suatu perundang-undangan yang ditujukan khusus untuk memberikan perlindungan kepada saksi dan korban, yaitu Undang-Undang Republik Indonesia Nomor 31 Tahun 2014 Tentang Perlindungan Saksi dan Korban (untuk selanjutnya disebut UUPSK). Namun sayangnya hanya korban yang memiliki ancaman sangat besar dalam memberikan kesaksiannya di pengadilan yang di lindungi oleh UUPSK. Dengan demikian tidak semua korban tindak pidana mendapatkan hakhak sebagaimana yang terdapat pada Pasal 5 Ayat (1) UUPSK.

Hukum pidana formil dari UU ITE merupakan pelaksanaan dari hukum materiil yang terdapat pada UU ITE. Hukum pidana formil dari UU ITE menyangkut dengan proses acara pidana yang pelaksanaannya telah diatur dalam UU ITE dan KUHAP. UU ITE memberikan sanksi pidana, diantaranya sanksi pidana atas tindak pidana penipuan melalui internet, yang diatur dalam pasal 42 ayat (2) UU ITE. Penerapan dari pasal 42 ayat (2) UU ITE tersebut dapat dilakukan dengan melalui proses peradilan pidana yang telah di atur dalam UU ITE dan KUHAP.

Hak korban yang terdapat pada KUHAP, diawali dengan pemberian hak untuk dapat melakukan laporan kepada penyelidik atau penyidik atas terjadinya penipuan melalui internet. Selain itu, korban juga memiliki hak untuk melakukan kontrol terhadap penyidik dan penuntut umum (Pasal 77 jo. 80 KUHAP) dan hak untuk menuntut ganti rugi akibat suatu tindak pidana melalui cara penggabungan perkara perdata dengan perkara pidana (Pasal 98 sampai dengan Pasal 101 KUHAP).

Undang-undang yang memberikan pengaturan secara khusus mengenai perlindungan terhadap korban, yaitu terdapat pada UUPSK. Akan tetapi perlindungan yang diberikan kepada korban hanya sebatas korban tindak pidana korupsi, tindak pidana narkotika/psikotropika, tindak pidana terorisme, dan tindak pidana lain yang mengakibatkan posisi Saksi dan Korban dihadapkan pada situasi yang sangat membahayakan jiwanya (Penjelasan Pasal 5 Ayat (2) UUPSK). Hal ini patut disayangkan, karena korban merupakan warga negara Indonesia, yang berhak untuk dilindungi haknya dan sama di hadapan hukum (equality before the law).

Perlindungan yang diberikan oleh UU ITE adalah berupa penyelesaian perkara dan pemberian sanksi pidana yang diberikan kepada tersangka atau terdakwa. Lain halnya dengan KUHAP, yang memberkan perlindungan terhadap korban berupa hak atas laporan, hak untuk melakukan kontrol terhadap penuntut umum, dan hak atas penggabungan penuntutan ganti kerugian antara perkara pidana dan perdata. Perbedaan yang kedua terlihat dari jenis tindak pidana yang dapat di selesaikan melalui hukum pidana formil. Tindak pidana yang dapat diselesaikan melalui hukum pidana pada UU ITE adalah seluruh tindak pidana yang diatur pada Pasal 27 UU ITE sampai dengan pasal 37 UU ITE.

Terhadap KUHAP menyangkut Seluruh tindak pidana yang terdapat pada KUHP dan UU khusus, diantaranya adalah UU ITE. Perbedaan yang ketiga dapat di fokuskan kepada fungsinya. Fungsi perlindungan yang diberikan oleh UU ITE adalah untuk menyelesaiankan sengketa untuk mempidanakan pelaku tindak pidana, diantaranya penipuan melalui internet, dengan menggunakan hukum pidana formil yang terdapatpada UU ITE. Sedangkan KUHAP adalah untuk menyelesaiakn sengketa akan tetapi, dalam pelaksanaannya lebih cenderung menggunakan KUHAP itu sendiri. 


\section{Kebijakan Perlindungan Hukum Bagi Korban Tindak Pidana Penipuan Melalui Internet}

Kebijakan penanggulangan kejahatan cyber crime, diantaranya penipuan melalui internet, merupakan salah satu bentuk perlindungan korban. Upaya menanggulangi kejahatan cyber crime, resolusi kongres PBB VIII/1990 mengenai “Computer-related Crime" mengajukan beberapa kebijakan antara lain sebagai berikut (Arief, 2010):

a. Menghimbau negara anggota untuk mrngintensifkan upaya-upaya penanggulangan penyalahgunaan komputer dengan cara memodernisasi hukum pidana formil dan materiil; mengembangkan tindakan untuk prncegahan dan pengamanan komputer; membuat masyarakat dan aparat penegak hukum peka terhadap pentingnya pencegahan kejahatan cyber crime; melakukan upaya pelatihat bagi aparat penegak hukum mengenai kejahatan cyber crime; memperluan "rules of ethics" dalam penggunaan komputer dan mengajarkan melalui kurikulum informatika; dan mengadopsi kebijakan perlindungan korban cyber crime sesuai dengan deklarasi PBB.

b. Menghimbau negar anggota meningkatkan kegiatan internasional dalam upaya penanggulangan cyber crime.

c. Merekomeendasikan kepada komite pengendalian dan pencegahan kejahatan PBB untuk menyebarluaskan pedoman dan standar untuk membantu negara anggota menghadapi cyber crime, mengembangkan penelitian tentang cyber crime, mempertimbangkan cyber crime sewaktu meninjau pengimplementasian perjanjian ekstradisi dan bantuan kerjasama di bidang penanggulangan kejahatan.

Upaya Indonesia untuk memodernisasi hukum pidana formil, salah satunya terdapat di RUU KUHP. RUU KUHP mengatur mengenai unsurunsur penipuan yang terdapat pada Pasal 611 RUU KUHP bagian kesatu mengenai penipuan, isinya adalah bahwa "Setiap orang yang secara melawan hukum dengan maksud menguntungkan diri sen- diri atau orang lain dengan memakai nama palsu atau kedudukan palsu, menyalahgunakan agama, menggunakan tipu muslihat atau rangkaian katakata bohong membujuk orang supaya memberikan suatu barang, membuat pengakuan utang, atau menghapus piutang, dipidana karena penipuan, dengan pidana penjara paling lama 4 (empat) tahun atau pidana denda paling banyak Kategori IV."

RUU KUHP telah memberikan perumusan delik dan menambahkan delik baru yang berkaitan dengan cyber crime, diantaranya penipuan melalui internet yang terdapat pada Buku II Bab VIII, mengenai Tindak Pidana yang Membahayakan Keamanan Umum Bagi Orang, Barang, Kesehatan dan Lingkungan Hidup. Bagian kelima pada Bab VIII mengatur mengenai Tindak Pidana terhadap Informatika dan Telematika dan terdiri dari 3 paragraf. Paragraf 1 mengatur mengenai Penggunaan dan Perusakan Informasi Elektronik dan Domain, paragraf 2 mengatur mengenai Tanpa Hak Mengakses Komputer dan Sistem Elektronik, dan paragraf 3 mengatur mengenai Pornografi Anak melalui Komputer. Tindak pidana sebagaimana dimaksud pada ayat (1) hanya dapat dituntut atas pengaduan dari orang yang terkena tindak pidana.

\section{Simpulan}

Aspek yuridis mengenai penindakan terhadap pelaku tindak pidana Penipuan melalui internet, menggunakan 2 (dua) peraturan hukum, yaitu Pasal 45 a Ayat (1) UU ITE Jo. Pasal 378 KUHP. Pemilihan kedua peraturan tersebut adalah karena unsur-unsur penipuan diatur pada KUHP sedangkan larangan mengenai penipuan melalui internet dan ketentuan pidana diatur pada UU ITE.

UU ITE memberikan perlindungan terhadap korban penipuan melalui internet berupa pemberian sanksi pidana kepada pelaku tindak pidana penipuan melalui internet. Sanksi pidana yang diberikan oleh UU ITE berupa pidana penjara dan pidana denda. Selain itu UU ITE juga memberikan perlindungan kepada korban penipuan melalui 
internet berupa penyelesaian sengketa. Hal ini ditandai dengan adanya substansi hukum pidana formil yang terdapat pada UU ITE.

Kebijakan penanggulangan kejahatan cyber crime, diantaranya penipuan melalui internet, merupakan salah satu bentuk perlindungan korban. Upaya menanggulangi kejahatan cyber crime, resolusi kongres PBB VIII/1990 mengenai "Computer-related Crime". RUU KUHP telah memberikan perumusan delik dan menambahkan delik baru yang berkaitan dengan cyber crime, diantaranya penipuan melalui internet yang terdapat pada Buku II Bab VIII, mengenai Tindak Pidana yang Membahayakan Keamanan Umum Bagi Orang, Barang, Kesehatan dan Lingkungan Hidup. Bagian kelima pada Bab VIII mengatur mengenai Tindak Pidana terhadap Informatika dan Telematika dan terdiri dari 3 paragraf.

\section{Saran}

Perlu untuk diberlakukan karena aturanaturan yang terdapat pada KUHP sekiranya sudah tidak sesuai lagi dengan perkembangan Ilmu Pengetahuan dan Teknologi (IPTEK) yang terdapat di Indonesia, mengingat Kitab Undang-Undang Hukum Pidana (KUHP) sendiri merupakan peninggalan dari kolonial Belanda. Oleh karena itu, perlu untuk diperbaharui karena kejahatan di dunia maya dirasa semakin hari semakin berkembang baik jenis kejahatan maupun modus operandinya.

\section{DAFTAR PUSTAKA}

Abdul Wahid dan Mohammad Labib, 2005, Kejahatan Mayantara (Cyber Crime), Refika Aditama, Bandung.

Adami Chazawi, 2003, Kejahatan Terhadap Harta Benda, Bayu Media, Malang.

Didik M. Mansur Arief, 2005, Cyber Law, Aspek Hukum Tekhnologi Informasi, Refika Aditama, Bandung.

Dwija Priyatno, 2006, Sistem Pelaksanaan Pidana Penjara di Indonesia, Refika Aditama, Bandung. Fajri, CyberCrime, fajri.freebsd.or.id/publication/ cybercrime.ppt, (diakses 5 Juni 2017).

Kitab Undang-Undang Hukum Acara Pidana (KUHAP)

Kitab Undang-Undang Hukum Pidana (KUHP)

Masruchin Rubai, 2001, Asas-asas Hukum Pidana, UM Press, Malang.

Naskah Akademik RUU ITE

Undang-Undang Republik Indonesia Nomor 19 Tahun 2016 tentang Perubahan Atas UndangUndang Republik Indonesia Nomor 11 Tahun 2008 tentang Informasi dan Transaksi Elektronik.

Undang-Undang Republik Indonesia Nomor: 31 Tahun 2014 tentang Perubahan Atas UndangUndang Republik Indonesia Nomor 13 Tahun 2006 tentang Perlindungan Saksi dan Korban. Wirjono Prodjodikoro, 2003, Tindak-tindak Pidana Tertentu di Indonesia, Refika Aditama, Bandung.

\section{How to Cite:}

Budiastanti, Dhaniar Eka. 2017. Perlindungan Hukum Terhadap Korban Tindak PidanaPenipuan Melalui Internet. Jurnal Cakrawala Hukum. 8 (1): 2232. 